\title{
Blood protein polymorphism and differentiation of selected indigenous cattle breeds
}

\author{
in Nigeria \\ ${ }^{* 1}$ Oladepo, A. D. and ${ }^{2}$ Salako A. E. \\ ${ }^{1}$ Animal Science Unit, Department of Agricultural Science, Adeyemi College of Education, \\ Ondo, Nigeria.

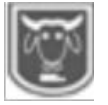 \\ ${ }^{2}$ Animal Breeding and Genetics Unit, Department of Animal Science, \\ University of Ibadan, Nigeria. \\ Abstract
}

Genetic variation is the basis of effective improvement in farm animals. Population differentiation is used for objective choice of parental genotypes that constitutes new hybrids in crossbreeding. In Nigeria, population characteristics of selected indigenous cattle breeds have not been fully documented. Therefore, blood protein electrophoretic patterns of selected indigenous cattle breeds in Nigeria were assessed. Blood samples $(5 \mathrm{~mL})$ were taken underneath the tail by venipuncture from 40 cattle randomly selected from each of the five breeds. The samples were subjected to cellulose acetate electrophoresis to determine the genetic variants of haemoglobin $(\mathrm{Hb})$, carbonic anhydrase (CA) and transferrin (Tf) following standard procedure. Data were analysed using descriptive statistics, cluster analysis and Euclidean genetic distance. Allele frequencies ranged between $0.10\left(\mathrm{Hb}^{\mathrm{A+}}\right)$ and $0.90\left(\mathrm{Hb}^{B+}\right), 0.11\left(\mathrm{CA}^{F+}\right)$ and $0.89\left(\mathrm{CA}^{F S}\right)$ and $0.02\left(\mathrm{Tf}^{\mathrm{A+}}\right)$ and $0.49\left(\mathrm{Tf} \mathrm{f}^{\mathrm{AE}}\right)$ across the breed. Two main clusters from the dendrogram were observed for each of $\mathrm{Hb}, \mathrm{CA}$ and Tf. Euclidean genetic distance at the blood protein polymorphism level between WF and $S G, W F$ and $R B$, WF and BK, WF and Muturu were 29, 30, 80 and 93, respectively. Genetic variants of transferrin were largest within breed which indicated potential for selection.

Keywords: Blood protein polymorphism, Breed differentiation, Indigenous cattle

\section{Introduction}

The initial step in characterization and differentiation is identification of distinct populations using information on their geographical and ecological isolation, traditional nomenclature, phenotypic distinctness and level of genetic differentiation among the population (Gizaw et al., 2011). Molecular characterization of farm animals is also important for the prevention of germplasm erosion by crossbreeding (Metta et al., 2004). It is however worthy to note that full extent of molecular variations and diversity of the Nigerian indigenous cattle remains largely unknown. Studies based on these molecular markers capable of unraveling phylogenetic history of biodiversity and development to better understand the genetic structure of the Nigerian cattle population is therefore necessary. Blood protein polymorphism markers had been used successfully in genetic variation of haemoglobin (Imumorin et al., 1999) and transferrin types in goats (Yakubu et al., 2010a; Yakubu et al., 2010b). Available literatures on characterization of these breeds using their blood protein polymorphism and reliable molecular markers are scanty and are yet to achieve full documentation coupled with the fact that it is one of the national priorities of Animal Genetic Resources (W'AnGR, 2004). Also, one of the priorities of FAO global strategy for improvement of livestock is the identification and characterization of all breeds of livestock (AGRI, 2006). 


\section{Polymorphism and differentiation of selected indigenous cattle breeds in Nigeria}

This study is designed to unveil the genotypic diversity among the selected Nigeria indigenous cattle breeds using data obtained from markers extracted from blood to assess diversity of the selected indigenous cattle populations in order to update published variations as well as document genetic distances between the populations. This will help to better understanding the genetics of Nigeria breeds of cattle for improvement and conservation goals and unravel the biodiversity that exist among the breeds using biochemical analysis. It will also provide a quantitative assessment of the diversity among the selected indigenous cattle breeds in Nigeria and thereafter provides light for objectives prediction and pave way for a better improvement in planning for a productive genetic improvement.

\section{Materials and methods Research animals}

Two hundred animals (forty from each breed of White Fulani, Sokoto Gudali, Red Bororo, Bornu Kuri and Muturu) were randomly selected ignoring sex from areas where they were found abundant within the country. All the animals were clinically healthy and free from internal and external parasites.

\section{aboratory analysis}

Blood sample $(5 \mathrm{~mL})$ was collected from each animal from underneath the tail by venipuncture into a ten milliliter $(10 \mathrm{~mL})$ heparinized tubes to prevent coagulation. The blood samples were kept cold by placing them in ice packs and care was taken to prevent exposure to extreme temperatures. Red blood cells (RBC) were prepared from the erythrocyte fraction of heparinized blood by centrifuging at 2500$3000 \mathrm{rpm}$ for $10 \mathrm{mins}$ at $4^{\circ} \mathrm{C}$. The RBC were washed in saline $(0.155 \mathrm{M} \mathrm{NaCl})$ three times and centrifuged at 2500-3000rpm for 5 mins at $4^{\circ} \mathrm{C}$. The RBCs were lysed with a fourfold volume of distilled $\mathrm{H}_{2} \mathrm{O}$ to release haemoglobin. The plasma fraction was separated from the erythrocyte fraction of heparinized blood by centrifuging at 2500$3000 \mathrm{rpm}$. The supernatant was used. The method used was as described by RIKEN (2006). Once plates have been removed from the tank, they were stained immediately with appropriate stain before they dried out. Once the plate had stained sufficiently to resolve the band, the stain was removed by washing and rinsing the gel plate several times with the specified destaining solution until sharp bands were visible. The bands were scored visually based on their migratory pattern as described by RIKEN (2006).

\section{Statistical analysis}

Direct counting was used for calculating gene frequencies. Frequencies generated were used to compute genotypic frequencies.

Genotypic frequencies were estimated using the formulae below:

At the three blood protein loci (haemoglobin, carbonic anhydrase and transferrin), two different alleles were observed for each of haemoglobin and carbonic anhydrase, while seven alleles were observed for transferrin. Thus, at the haemoglobin $(\mathrm{Hb})$ locus, the two different alleles observed were A and B. Similarly, at the carbonic anhydrase (CA) locus, the two different alleles observed were $\mathrm{S}$ and $\mathrm{F}$, However, at the transferrin (Tf) locus, seven different alleles observed were A, B, C, D, E, $\mathrm{G}$ and $\mathrm{P}$. The allele frequencies for the cattle populations at haemoglobin locus $\mathrm{Hb}^{\mathrm{A}}$ and $\mathrm{Hb}^{\mathrm{B}}$ ranges from $0.23-0.36$ and $0.64-0.77$ respectively while the allele frequencies of carbonic anhydrase $\mathrm{Ca}^{\mathrm{S}}$ and $\mathrm{Ca}^{\mathrm{F}}$ ranges from $0.81-0.88$ and 0.12 and 0.91 respectively. Similarly, the allele frequencies of 
Oladepo and Salako

Table 1: Genotypic distribution of haemoglobin, carbonic anhydrase and transferrin loci of the five cattle breeds

\begin{tabular}{|c|c|c|c|c|c|c|}
\hline \multirow{3}{*}{$\begin{array}{l}\text { Loci } \\
\text { Haemoglobin }\end{array}$} & \multirow{3}{*}{$\begin{array}{l}\text { Genotypes } \\
\text { AA }\end{array}$} & \multicolumn{4}{|c|}{ Breeds } & \multirow{3}{*}{$\begin{array}{l}\text { Muturu } \\
10\end{array}$} \\
\hline & & White Fulani & Sokoto Gudali & Red Bororo & Bornu Kuri & \\
\hline & & 07 & 05 & 0 & 03 & \\
\hline & $\mathrm{AB}$ & 15 & 11 & 18 & 12 & 4 \\
\hline & BB & 18 & 24 & 21 & 25 & 26 \\
\hline Carbonic & SS & 27 & 31 & 31 & 29 & 33 \\
\hline \multirow[t]{2}{*}{ Anhydrase } & FS & 9 & 7 & 6 & 7 & 4 \\
\hline & FF & 4 & 2 & 3 & 4 & 3 \\
\hline \multirow[t]{17}{*}{ Transferrin } & AA & 3 & 11 & 13 & 9 & 12 \\
\hline & $\mathrm{AB}$ & 2 & 4 & 3 & 2 & 2 \\
\hline & $\mathrm{AC}$ & 1 & - & - & 2 & 1 \\
\hline & $\mathrm{AD}$ & - & 1 & 3 & - & 2 \\
\hline & $\mathrm{AE}$ & 1 & - & 2 & 1 & 1 \\
\hline & $\mathrm{AG}$ & - & 2 & - & - & - \\
\hline & $\mathrm{BB}$ & 12 & 8 & 5 & 9 & 3 \\
\hline & $\mathrm{BC}$ & 2 & 1 & 1 & 1 & 5 \\
\hline & $\mathrm{BD}$ & - & - & 2 & 2 & 1 \\
\hline & $\mathrm{BE}$ & 3 & - & 3 & - & 2 \\
\hline & $\mathrm{BP}$ & 1 & 3 & - & 1 & 3 \\
\hline & $\mathrm{CC}$ & 9 & 5 & - & 6 & 1 \\
\hline & $\mathrm{CD}$ & - & - & 1 & 3 & 2 \\
\hline & $\mathrm{CE}$ & 1 & 1 & 2 & - & - \\
\hline & $\mathrm{CP}$ & 1 & 3 & 1 & 2 & - \\
\hline & $\mathrm{EE}$ & 4 & 1 & 2 & 2 & 2 \\
\hline & GD & - & - & 2 & - & 3 \\
\hline
\end{tabular}

transferrin $\mathrm{Tf}^{\mathrm{A}}, \mathrm{Tf}^{\mathrm{B}}, \mathrm{Tf}^{\mathrm{C}}, \mathrm{Tf}^{\mathrm{D}}, \mathrm{Tf}^{\mathrm{E}}, \mathrm{Tf}^{\mathrm{G}}$ and $\mathrm{Tf}^{\mathrm{P}}$ ranges from $0.14-0.43,0.20-0.39,0.05-$ $0.29,0.03-0.66,0.09-0.17,0.03-0.08$ and $0.03-0.08$ respectively (Table 2 ). All loci were polymorphic. Haemoglobin B allele occurred at a higher frequency in all the five cattle breeds investigated: $0.64,0.74,0.75$, 0.77 and 0.70 in White Fulani, Sokoto Gudali, Red Bororo, Bornu Kuri and Muturu respectively (Table 2). All the five cattle breeds investigated had $\mathrm{F}$ and $\mathrm{S}$ alleles at the carbonic anhydrase locus. The $\mathrm{S}$ allele at the CA locus occurred at the higher frequencies in all the five cattle breeds investigated, $0.79,0.86,0.85,0.81$ and 0.88 in White Fulani, Sokoto Gudali, Red Bororo, Bornu Kuri and Muturu respectively (Table 2). Seven co-dominant alleles namely, A, B, $\mathrm{C}, \mathrm{D}, \mathrm{E}, \mathrm{G}$ and $\mathrm{P}$ controlling genotypes were observed at the transferrin locus. The A, B, C and $\mathrm{P}$ alleles were present in all the breeds sampled. The D allele was found only in Sokoto Gudali, Red Bororo, Bornu Kuri and Muturu; E allele was found in White Fulani, Red Bororo, and Bornu Kuri while G allele was found in Sokoto Gudali, Red Bororo and Muturu (Table 2). The A allele was the most frequent all the five breeds compared to other alleles at this locus. 
Polymorphism and differentiation of selected indigenous cattle breeds in Nigeria

Table 2: Allele frequencies at the haemoglobin, carbonic anhydrase and transferrin loci of White

\begin{tabular}{lllllll}
\hline Locus & Allele & White Fulani & Sokoto Gudali & Red Bororo & Bornu Kuri & Muturu \\
\hline $\mathrm{Hb}$ & $\mathrm{A}$ & 0.36 & 0.26 & 0.25 & 0.23 & 0.30 \\
& $\mathrm{~B}$ & 0.64 & 0.74 & 0.75 & 0.77 & 0.70 \\
$\mathrm{CA}$ & $\mathrm{S}$ & 0.79 & 0.86 & 0.85 & 0.81 & 0.88 \\
$\mathrm{Tf}$ & $\mathrm{F}$ & 0.21 & 0.14 & 0.15 & 0.91 & 0.12 \\
& $\mathrm{~A}$ & 0.136 & 0.36 & 0.43 & 0.29 & 0.38 \\
& $\mathrm{~B}$ & 0.386 & 0.30 & 0.20 & 0.28 & 0.23 \\
& $\mathrm{C}$ & 0.290 & 0.19 & 0.05 & 0.24 & 0.08 \\
& $\mathrm{D}$ & - & 0.03 & 0.08 & 0.66 & 0.11 \\
& E & 0.169 & - & 0.11 & 0.09 & 0.09 \\
& G & - & 0.03 & 0.05 & - & 0.08 \\
& P & 0.045 & 0.08 & 0.08 & 0.04 & 0.03 \\
\hline
\end{tabular}

Fulani, Sokoto Gudali, Red Bororo, Bornu Kuri and Muturu cattle breeds

$\mathrm{Hb}=$ Haemoglobin; $\mathrm{CA}=$ Carbonic anhydrase, $\mathrm{Tf}=$ Transferrin

\section{Discussion}

In this study, HbB type has a very high frequency in cattle of northern savannah zone, the region in which the White Fulani, Red Bororo, Bornu Kuri and Sokoto Gudali are predominantly found. The breeds have $\mathrm{HbB}$ conferred on them for survival in the drier savannah regions where the breeds are found. This predominance appears to be of adaptive significance in the arid regions to which these breeds fit. This is due to the decreased haematocrit values, lower blood viscosity and higher availability of water associated with $\mathrm{HbB}$ blood types compared to HbA types. This seems to be of adaptive significance in habitats characterized by the aridity of the climate such as the northern zone of Nigeria. This confirmed the reports of Tsunoda et al. (2006) that Haemoglobin A allele has a high affinity for oxygen and is important for survival in mountain areas with attitudes over $3000 \mathrm{~m}$. Difference in haemoglobin A and B in the breeds may be attributed to the selective advantages of haemoglobin in difference geographical regions.

The predominance of $\mathrm{Hb}^{\mathrm{B}}$ in Muturu and Bornu Kuri in this study agreed with the report of Bangham and Blumberg (1958); Braend and Khanna, (1968); FAO (1976);
Queval, (1982) that humpless cattle predominantly have $\mathrm{Hb}^{\mathrm{B}}$ and traces of $\mathrm{Hb}^{\mathrm{A}, \mathrm{C}}$ and $\mathrm{D}$ and that these traces of haemoglobin genotypes in the humpless cattle are predominant in the humped zebu. The different sequence of $\mathrm{Hb}$ in these humpless cattle compared with that of the zebu is an indication that they may be genetically different and further evidence of different ancestries of these cattle types. These alleles differentiate these humpless cattle from the humped zebu and this was in agreement with reports by Joshi et al. (1957) and Mason (1988). Braend (1972) and Tejedor et al.(1986) also reported that there is high prevalence of $\mathrm{Hb}^{\mathrm{A}}$ in Bos taurus cattle and was corroborated by Brasad et al.(1983) in some Indian taurus cattle breeds. This observation is contrary to the high altitude theory by some authors in sheep.

The five breeds in this current study were polymorphic at $\mathrm{CA}$ locus. The $\mathrm{CA}^{\mathrm{s}}$ was the most common in all the breeds. This current investigation was at variant with what Ibeagha-Awemu et al. (2004) reported, they discovered that Muturu showed monomorphism at CA locus. The distribution of alleles at the transferrin locus among the five cattle breeds and their number within each breed were dispersed. 


\section{Oladepo and Salako}

The observed differences at the transferrin alleles indicate a clear genetic differentiation among the selected indigenous cattle breeds of Nigeria studied. This showed that genetic variants of transferrin within breed were largest and this is an indication of their potential for selection. In this study, Muturu exhibited high frequency of homozygotes genotypes of $\mathrm{Tf}^{\mathrm{EE}}$ and $\mathrm{Tf}^{\mathrm{BB}}$ while White Fulani, Red Bororo and Sokoto Gudali had higher frequencies of $\mathrm{Tf}^{\mathrm{DD}}$ and $\mathrm{Tf}^{\mathrm{AA}}$ than other genotypes; this is an indication that these breeds could be selected for the economic trait associated with these genotypes.

Observation at Transferrin locus are generally difficult to compare with the result obtained in other studies because of the different electrophoretic media used by other researchers and subsequently different resolution power, that is, starch gel and polyacrylamide gel electrophoresis (Ibeagha-Awemu et al., 2004; Akinyemi and Salako, 2012). Though, there is likelihood of significance deviations of allele frequencies as a result of crossing and linking, sample error, population bottlenecks, random genetic drift, high gene flows, admixture, interbreeding and sharing common ancestry among the breeds. The influence of zebu genes (White Fulani, Sokoto Gudali, and Red Bororo) on taurine (Bornu Kuri) was also detected at transferrin locus and this confirmed what had earlier reported by Ibeagha-Awemu et al. (2004).

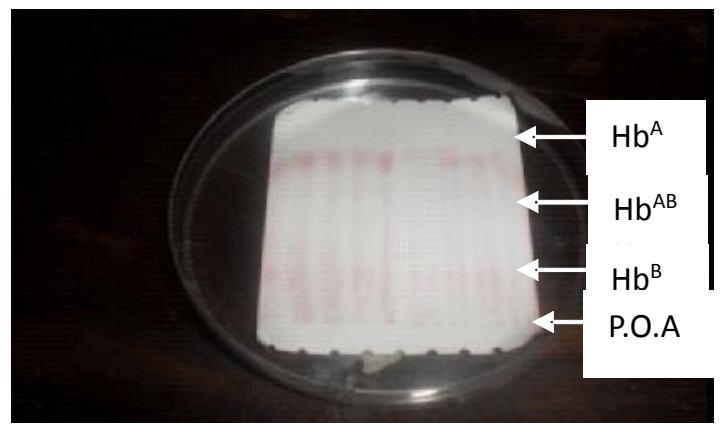

Plate 1: Electrophoregram showing migration of haemoglobin genotypes on cellulose acetate gel P.O.A. = Point of Application

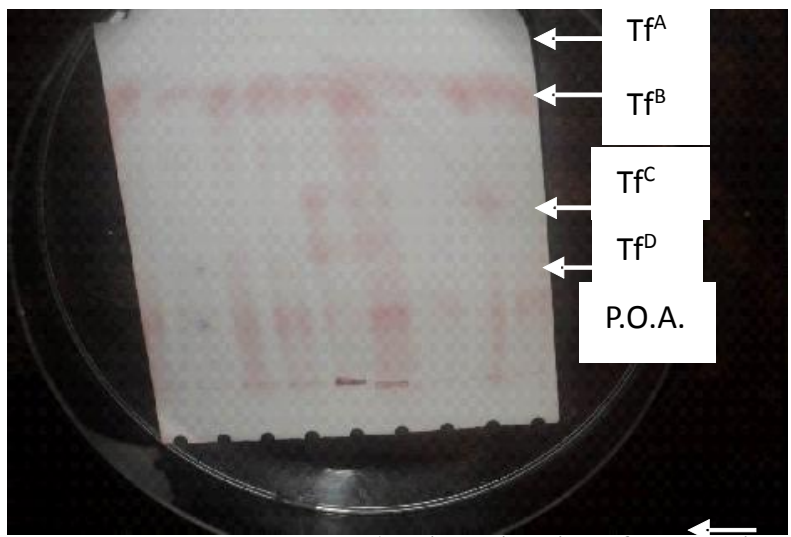

Plate 2 : Electrophoregram showing migration of transterrin genotypes on cellulose acetate gel P.O.A. $=$ Point of Application 
Polymorphism and differentiation of selected indigenous cattle breeds in Nigeria

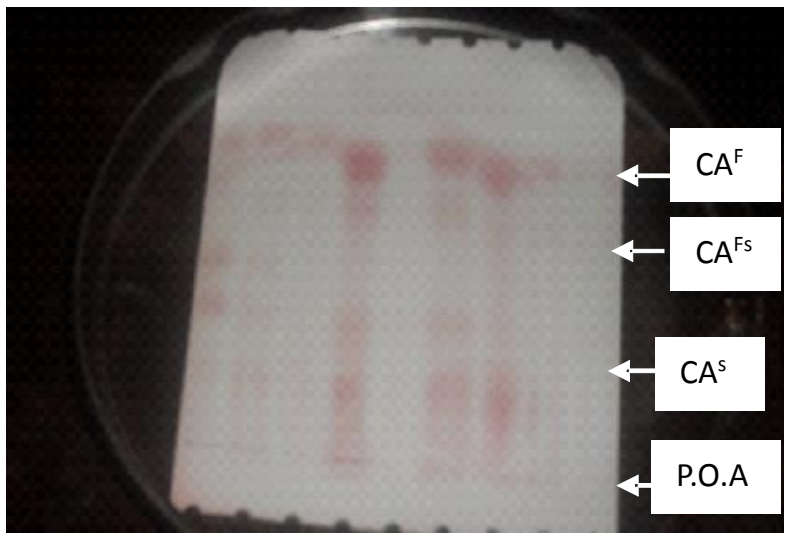

Plate 3: Electrophoregram showing migration of transferrin genotypes on cellulose acetate gel P.O.A. $=$ Point of Application

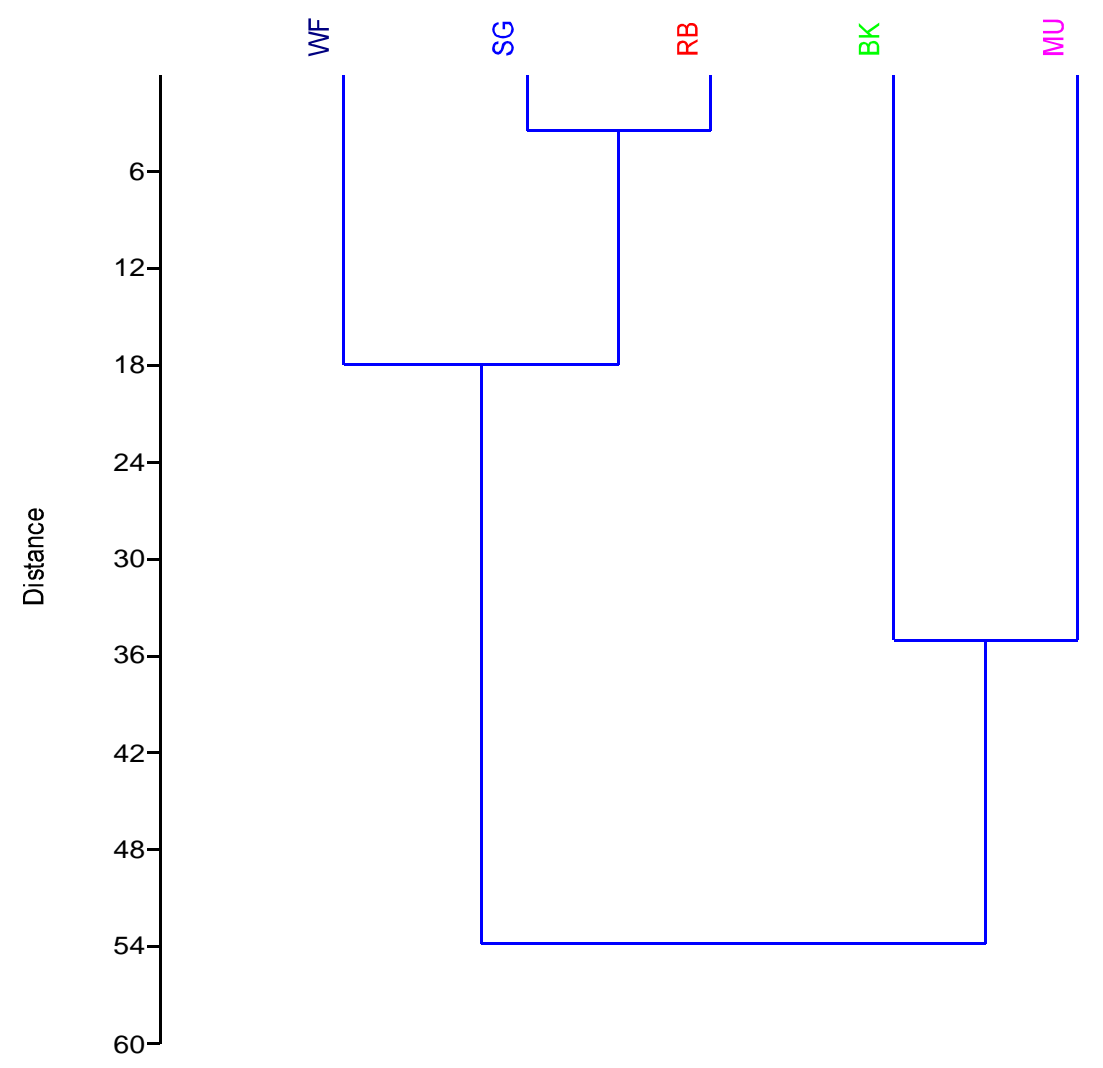

Fig. 1: Dendrogram showing genetic relationship among White Fulani, Sokoto Gudali, Red Bororo, Bornu Kuri and Muturu Breed of cattle at haemoglobin locus. 


\section{Oladepo and Salako}

\section{Conclusion}

The value of genetic distance estimates obtained in this study using blood proteins polymorphism were higher between nonrelated breeds than between breeds which had common ancestors and this shows the existence of the substantial genetic differentiation among the cattle populations and this is provide room for selection and conservation purposes. The values obtained could be due to fact that the loci examined coded for a few proteins which represent a small part of the entire genome. It is therefore recommended

that a comprehensive research be carried out using DNA sequencing, Restriction Fragment Length

Polymorphisms (RFLPs) and microsatellite markers or Simple Tandem Repeats (STRs) to differentiate,

characterize and identify specific genes that are linked to some economic traits, their hardiness and

resistance to diseases.

\section{References}

AGRI 2006. Genetic characterization and distances of indigenous livestock b $\quad \mathrm{r} \quad \mathrm{e} \quad \mathrm{e} \quad \mathrm{d} \quad \mathrm{s}$. http.//www.arc.agric.za/lome.asp? pid $=56$

Akinyemi, M. O. and Salako, A. E. 2012. Genetic relationship among Nigerian indigenous sheep populations using blood protein polymorphism. Agricultural Science and Technology, Vol. 4, No. 2, pp 107-112.

Banhgham, A. D. and Blumberg, B. S. 1958. Distribution of electrophoretically differ haemoglobins in some breeds of Europe and Africa. Nature 181, 1551.

Braend, M. 1972. Studies on the relationships between cattle breeds in Africa, Asia and Europe: Evidence obtained by studies of blood groups and protein polymorphism. World Rev. Anim. Prod, v. 8, p. 9-14.

Braend, M. and Khana, N. D. 1968. Haemoglobin and transferring types of some West African cattle. Animal Prod. 10:129-134.

FAO 1976. Rapport de la premiere Consultation d'expert sur la recherché concernant la trypanotolerance, Rome, 16 - 19 mars. 42 pp.

Gizaw, S., Komen, H., Hanotte, O., Van Arendonk, J.A.P: Kemp, S., Aynalem, H. Mwai, Ol and Dessie, T. 2011. Characterization and conservation of indigenous sheep genetic resources: a practical framework for developing countries. ILRI Research Report No. 27. Nairobi, Kenya. ILRI.

Groeneveld, L.F., Lenstra, J.A., Eding H., Toro, M.A; Scherf, B., Pilling, D., Negrini, R., Finlay, E.K., Jianlin, H., Groeneveld, E. Weigend, S. and GLOBALDIV Consortium. 2010. Genetic diversity in farm animals a review. Anim. Genet. 41(Suppl.1); 6-31.

Ibeagha - Awemu, E. M., Jager, S. and Erhardt G. 2004. Polymorphisms in blood proteins of Bos indicus and Bos Taurus cattle breed of Cameroon and Nigeria, and Description of New Albumin Variants. Biochemical Genetics. Vol. 42, No. 5/6: 181-197.

Imumorin, I. G., Ologun, A. G. and Oyeyemi, M. O. 1999. Preliminary observations on effects of heamoglobin genotype and estimate of genetic distance at the $\mathrm{Hb}$ locus in 


\section{Polymorphism and differentiation of selected indigenous cattle breeds in Nigeria}

West African Dwarf and Red Sokoto goats. Trop. J. Anim. Sci., 1: $1-9$.

Joshi, N. R., McLaughin, E. A. and Philips, R. W. 1957. Types and breeds of African cattle. FAO Agricultural Studies. No. 37 FAO, Rome. 297 pp.

Mason, J. L. 1988. A world dictionary of livestock breeds, types and varieties. 3rd Ed, Wallingford, UK, CAB International, 348pp.

Metta, M., Kanginakudru, S., Gudiseva, N. and Nagaraju, J. 2004. Genetic characterization of the Indian cattle breeds Ongole and Deoni (Bos Indicus), using microsatellite markers- A preliminary Study. BMC Genetic, 5:16 (doi: 1186/1471-2156-5-6 or http://www.biomedcentral.com/14 71-22156/5/16).

Queval, R., Petit, J. P., Tacher, G., Provost, A. and Pagot, J. 1982. Le Kouri: race bovine du lac Tchad I. introduction generate a son etude zoo technique et biochimique: Origines et ecological de la race. Revue d'Eleverage et de Medecine Veterinaire des pays Tropicaux 24(4): 667-687.
RIKEN. 2006. Genetic Quality Monitoring by Biochemical Izozymes. RIKEN Bio Resource Centre.

Tejedor, T., Rodellar, C., and Zaragosa, P. 1986. Analysis of genetic variation in cattle breeds using electrophoresis studies. Arch. Zootec. V. 35, p. 225-237.

W'AnGR. 2004. State of the World's Animal Genetic Resources. Nigeria Country Report.pp.67

Yakubu, A., Raji, A. O. and Omeje, J. N. 2010 a. G e net i c a nd phenotypicdifferentiation of qualitative traits in Nigerian indigenous goat and sheep populatiins. Asian Research Publishing Network (ARPN) Journal of Agricultural and Biological Science 5 (2): 58-66.

Yakubu, A., Salako, A. E., Imumorin, I. G. Ige, A. O. and Akinyemi, M. O. 2010b. Discriminant analysis of morphometric differentiation in the West African Dwarf and Red Sokoto goat. South African Journal of Animal Science 40 (4): 89-97.

Received: $10^{\text {th }}$ May, 2017

Accepted: 21 ${ }^{\text {st }}$ August, 2017 